Fixed Point Theory, 21(2020), No. 2, 697-706

DOI: $10.24193 /$ fpt-ro.2020.2.49

http://www.math.ubbcluj.ro/ nodeacj/sfptcj.html

\title{
WARDOWSKI-FENG-LIU TYPE FIXED POINT THEOREMS FOR MULTIVALUED MAPPINGS
}

\author{
HEMANT KUMAR NASHINE* AND ZORAN KADELBURG** \\ *Department of Mathematics, School of Advanced Sciences \\ Vellore Institute of Technology, Vellore-632014, TN, India \\ Department of Mathematics and Applied Mathematics, University of Johannesburg, \\ Kingsway Campus, Auckland Park 2006, South Africa \\ E-mail: drhknashine@gmail.com, hemant.nashine@vit.ac.in \\ ** University of Belgrade, Faculty of Mathematics \\ Studentski trg 16, 11000 Beograd, Serbia \\ E-mail: kadelbur@matf.bg.ac.rs (Corresponding author)
}

\begin{abstract}
In this work, we present some Wardowski-Feng-Liu type fixed point theorems for multivalued mappings in complete (ordered) metric spaces. The obtained results generalize and improve several existing theorems in the literature. The given notions and outcome are illustrated by an appropriate example. An application to existence of solutions for Fredholm-type integral inclusions is presented.
\end{abstract}

Key Words and Phrases: F-contraction, Fixed point of a multivalued mapping, Fredholm integral inclusion.

2010 Mathematics Subject Classification: 47H10, 54H25.

Acknowledgements. The authors are indebted to the referee for useful comments that helped us to improve the text. The second author is grateful to the Ministry of Education, Science and Technological Development of Serbia, Grant no. 174002.

\section{REFERENCES}

[1] M. Abbas, T. Nazir, T. Aleksić Lampert, S. Radenović, Common fixed points of set-valued Fcontraction mappings on domain of sets endowed with directed graph, Comput. Appl. Math., 36(2017), no. 4, 1607-1622.

[2] I. Altun, G. Durmaz, G. Minak, S. Romaguera, Multivalued almost F-contractions on complete metric spaces, Filomat, 30(2016), no. 2, 441-448.

[3] I. Altun, G. Minak, H. Dağ, Multivalued F-contractions on complete metric space, J. Nonlinear Convex Anal., 16(2015), no. 4, 659-666.

[4] I. Altun, M. Olgun, G. Minak, On a new class of multivalued weakly Picard operators on complete metric spaces, Taiwanese J. Math., 19(2015), no. 3, 659-672.

[5] S. Chandok, H. Huang, S. Radenović, Some fixed point results for the generalized F-Suzuki type contractions in b-metric spaces, Sahand Commun. Math. Analysis, 11(2018), no. 1, 81-89.

[6] Y. Feng, S. Liu, Fixed point theorems for multi-valued contractive mappings and multi-valued Caristi type mappings, J. Math. Anal. Appl., 317(2006), 103-112. 
[7] G. Minak, I. Altun, S. Romaguera, Recent developments about multivalued weakly Picard operators, Bull. Belg. Math. Soc. Simon Stevin, 22(2015), no. 3, 411-422.

[8] G. Minak, M. Olgun, I. Altun, A new approach to fixed point theorems for multivalued mappings, Carpathian J. Math., 31(2015), no. 2, 241-248.

[9] H.K. Nashine, R.P. Agarwal, Z. Kadelburg, Solution to Fredholm integral inclusions via $\left(F, \delta_{b}\right)$ contractions, Open Math., 14(2016), 1053-1064.

[10] A. Nicolae, Fixed point theorems for multi-valued mappings of Feng-Liu type, Fixed Point Theory, 12(2011), no. 1, 145-154.

[11] A. Petruşel, Integral inclusions. Fixed point approaches, Ann. Soc. Math. Polon. Comment. Math., 40(2000), 147-58.

[12] A. Petruşel, G. Petruşel, J-C. Yao, A study of a system of operator inclusions via a fixed point approach and applications to functional-differential inclusions, Carpathian J. Math., 32(2016), no. 3, 349-361.

[13] M. Sgroi, C. Vetro, Multi-valued F-contractions and the solution of certain functional and integral equations, Filomat, 27(2013), no. 7, 1259-1268.

[14] N. Van Dung, V. Le Hang, A fixed point theorem for generalized F-contractions on complete metric spaces, Vietnam J. Math., 43(2015), 743-753.

[15] D. Wardowski, Fixed point theory of a new type of contractive mappings in complete metric spaces, Fixed Point Theory Appl., 94(2012).

[16] D. Wardowski, N. Van Dung, Fixed points of F-weak contractions on complete metric spaces, Demonstratio Math., 47(2014), no. 1, 146-155.

Received: July 11, 2018; Accepted: January 10, 2019. 
